\title{
PENGEMBANGAN PERANGKAT PEMBELAJARAN IPA BERBASIS INKUIRI TERBIMBING UNTUK MENUMBUHKAN KETERAMPILAN BERPIKIR KRITIS PESERTA DIDIK PADA MATERI ASAM, BASA, DAN GARAM SMP NEGERI 1 BULUKUMBA
}

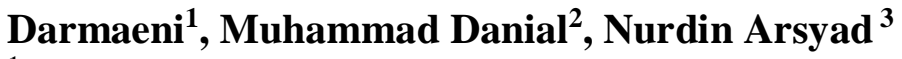 \\ ${ }^{1}$ Guru SMP Negeri 1 Bulukumba \\ ${ }^{2,3}$ Dosen Program Pascasarjana Universitas Negeri Makassar \\ Email:darmaeni.235@gmail.com
}

\begin{abstract}
ABSTRAK
Tujuan penelitian ini adalah (i) untuk menghasilkan perangkat pembelajaran IPA berbasis inkuiri terbimbing pada materi asam, basa, garam; (ii) untuk mendeskripsikan kevalidan, keefektifan, dan kepraktisan perangkat pembelajaran IPA berbasis inkuiri terbimbing. Penelitian ini merupakan penelitian pengembangan yang difokuskan untuk mengembangkan perangkat pembelajaran IPA berbasis inkuiri terbimbing pada materi asam, basa, dan garam. Perangkat pembelajaran yang dihasilkan dalam penelitian ini adalah RPP, Buku Ajar Peserta Didik (BAPD), Lembar Kerja Peserta Didik (LKPD). Model pengembangan yang digunakan dalam penelitian ini mengacu pada model Thiagarajan atau 4-D yang terdiri dari tahap pendefinisian, tahap perancangan, tahap pengembangan dan tahap penyebaran. Perangkat pembelajaran yang dihasilkan dalam penelitian ini divalidasi oleh dua orang ahli dengan hasil penilaian berada pada kategori sangat valid untuk RPP dan BAPD dan kategori valid untuk LKPD serta dapat digunakan dengan sedikit revisi. Pada penelitian ini uji coba dilakukan satu kali. Uji coba dilakukan pada kelas $\mathrm{VII}_{2}$ SMP Negeri 1 Bulukumba. Hasil yang diperoleh pada uji coba tersebut, yaitu: (1) perangkat pembelajaran IPA berbasis inkuiri terbimbing sudah praktis, (2) perangkat pembelajaran IPA berbasis inkuiri terbimbing pada materi asam, basa, dan garam sudah efektif karena telah memenuhi 3 dari 4 indikator keefektifan, yaitu: ketuntasan klasikal tes hasil belajar telah tercapai, aktivitas peserta didik pada setiap pertemuan berada pada rentang batas toleransi, dan respon peserta didik berada pada kategori positif. Dengan mengikuti tahap pengembangan di atas, diperoleh perangkat pembelajaran IPA berbasis inkuiri terbimbing pada materi Asam, Basa, dan Garam yang memenuhi kriteria valid, praktis, dan efektif.
\end{abstract}

Kata kunci: Inkuiri Terbimbing, Keterampilan Berpikir Kritis

\begin{abstract}
The purpose of this study was (i) to produce the guided inquiry-based science learning on the material acids, bases, salts; (Ii) to describe the validity, effectiveness and practicality of the device guided inquiry-based science learning. This research is a development that is focused on developing tools guided inquiry-based science learning on the material acids, bases and salts. Learning tools generated in this study is the RPP, Textbook of Students (BAPD), Worksheet Students (LKPD). The development model used in this study refers to the model Thiagarajan or 4-D comprising the step of defining, designing stage, stage of development and deployment phase. Learning tools generated in this study are validated by two experts with the assessment result is in the category very valid for the RPP and BAPD and valid for LKPD category and can be used with minimal revision. In this study, the test was carried one. Tests performed on grade VII2 SMP Negeri 1 Bulukumba. The results obtained in these trials, namely: (1) the learning device science-based guided inquiry has been practical, (2) the learning device science-based guided inquiry on material acids, bases, and salts have been
\end{abstract}


effective because it has met three of the four indicators of effectiveness, namely: classical completeness achievement test has been reached, the activity of learners at each meeting is in the range of tolerance limits, and the response of students that are in the positive category. By following the above development, obtained the guided inquiry-based science learning in materials Acids, Bases, and Salts are valid criteria, practical, and effective.

Keywords: Guided Inquiry, Critical Thinking Skills

\section{PENDAHULUAN}

Konsep pembelajaran IPA yang dijelaskan dalam Kurikulum Tingkat Satuan Pendidikan (KTSP) berhubungan dengan cara mencari tahu tentang gejala-gejala alam secara sistematis, sehingga IPA bukan hanya penguasaan kumpulan pengetahuan yang berupa fakta-fakta, konsep-konsep, atau prinsip-prinsip saja tetapi juga merupakan suatu proses penemuan. Oleh karena itu Pendidikan IPA juga diarahkan untuk proses inkuiri dan berbuat sehingga dapat membantu peserta didik untuk memperoleh pemahaman yang lebih mendalam tentang alam sekitar (Trianto, 2013 : 153).

Seperti yang telah dijelaskan di atas bahwa mata pelajaran IPA merupakan mata pelajaran yang berkaitan erat dengan cara mencari tahu tentang gejala-gejala alam secara sistematis, ini berarti mata pelajaran IPA erat kaitannya dengan kemampuan menggunakan ketermpilan berpikirnya. Keterlibatan kita dalam berbagai proses berpikir berarti kita harus mengusai keterampilan berpikir dari tingkat rendah (Lower Odrder Thinking Skill - LOTS) sampai keterampilan berpikir tingkat tinggi (Higher Order Thinking Skill - HOTS). LOTS adalah keterampilan berpikir yang hanya menuntut seseorang untuk mengingat, memahami dan mengaplikasikan sesuatu rumus atau hukum, Sedangkan HOTS adalah keterampilan yang lebih dari sekedar mengingat, memahami dan mengaplikasikan (A. Thomas \& G. Thorne dalam Al'Azzy).

Menurut Resnick dan Thomson (2008) dalam Fatmawati (2013) bahwa berpikir tingkat dasar (Lower Order Thinking) hanya menggunakan kemampuan terbatas pada hal-hal rutin dan bersifat mekanis, sedangkan berpikir tingkat tinggi (Higher
Order Thinking) membuat peserta didik untuk menginterpretasikan, menganalisa atau bahkan mampu memanipulasi informasi sebelumnya sehingga tidak monoton.

Berpikir kritis merupakan salah satu aspek dari kegiatan berpikir tingkat tinggi (Higher Order Thinking Skill - HOTS). Dalam suatu proses pembelajaran IPA, jika seorang peserta didik menggunakan keterampilan berpikir tingkat tingginya maka pembelajaran tersebut akan menjadi pembelajaran yang bermakna. Karena anak tidak hanya harus mengingat dan menghafal konsep yang ditemui pada pelajaran, tetapi peserta didik juga harus mampu memecahkan suatu masalah dan membuat keputusan-keputusan yang rasional mengenai sesuatu yang dapat ia yakini kebenarannya. Dengan begitu anak juga tidak akan mudah lupa terhadap konsep IPA.

Berdasarkan pengalaman penulis sebagai guru IPA SMP Negeri 1 Bulukumba tentang kegiatan pembelajaran IPA di sekolah tersebut adalah materi pelajaran dominan disajikan melalui model pembelajaran langsung dengan metode ceramah. Begitupula materi pembelajaran tidak dikemas menyesuaikan kondisi peserta didik sebab berpatokan pada buku paket yang ada sehingga terkesan monoton dan memaksa anak untuk berbuat sesuai apa yang diperintahkan oleh guru, Walupun peneliti pernah mencoba menerapkan model pembelajaran Inkuiri dalam bentuk Penelitian Tindakan Kelas (PTK) tetapi belum menghasilakn perangkat pembelajaran yang tepat, dimana perangkat yang dibuat belum optimal dapat menunjang proses pembelajaran. Keterbatasan dalam hal pembuatan RPP yang belum menjelaskan kegiatan pembelajaran secara 
menyeluruh dan kesesuaian penyajian materi dengan waktu yang tersedia, sumber belajar berupa buku yang digunakan oleh peserta didik masih menggunakan buku paket yang telah disediakan di sekolah (buku paket pinjaman dari perpustakaan). Sedikit peserta didik yang memiliki koleksi buku pribadi/sendiri untuk dapat dipelajari sendiri di rumah., begitu pula penggunaan LKPD yang hanya memberi instruksi langsung kepada peserta didik,sehingga melakukan kegiatan sesuai dengan instruksi yang terdapat dalam LKPD tanpa memikirkan alasan pengerjaan tahap demi tahap hal ini berakibat kurangnya pengalaman pada peserta didik untuk bekerja secara ilmiah.

Rendahnya kemampuan berpikir kritis peserta didik juga terjadi di SMP Negeri 1 Bulukumba. Berdasarkan hasil observasi dan wawancara dengan guru IPA di SMP Negeri 1 Bulukumba, diketahui bahwa guru masih kurang menggali kemampuan berpikir kritis dalam proses pembelajaran. Hal tersebut terlihat dari kegiatan guru dan peserta didik pada saat kegiatan pembelajaran antara lain: metode pembelajaran yang biasanya digunakan adalah ceramah, diskusi, yaitu guru memberikan penjelasan, kemudian tanya jawab, dan ditutup dengan pemberian tugas atau latihan. Adapun Kelemahan diskusi yang digunakan oleh guru selama ini adalah tidak semua peserta didik dapat berperan aktif dalam proses pembelajaran. Keterlibatan peserta didik kurang optimal disebabkan oleh banyaknya peserta didik yang pasif mengikuti pelajaran karena kegiatan pembelajaran berpusat pada guru, serta guru tidak mengajak peserta didik berlatih untuk menganalisis suatu informasi data atau argument, dengan kata lain tidak melatih untuk mengembangkan kemampuan berpikir kritisnya.

Menurut Puskur (2007) dalam Apriliyana U (2012) bahwa proses pembelajaran sains hendaknya dilaksanakan secara inkuiri ilmiah (Scientic inquiry) untuk menumbuhkan kemampuan berpikir, bekerja dan bersikap ilmiah serta mengkomunikasikannya sebagai aspek penting kecakapan hidup. Pembelajaran yang berpusat pada peserta didik (student centered), misalnya inkuiri tepat digunakan untuk mengembangkan kemandirian peserta didik dan mampu memberdayakan kemampuan berpikir kritis.

Kemampuan berpikir kritis peserta didik sangat penting dikembangkan demi keberhasilannya dalam pendidikan secara khusus dan dalam kehidupan bermasyarakat secara umum. Salah satu alternatif model pembelajaran IPA yang dapat diterapkan untuk melatih peserta didik bekerja secara ilmiah dan mengembangkan kemampuan berpikir dalam hal menumbuhkan keterampilan berpikir kritis dan hasil belajar peserta didik hingga dapat memberikan penguatan terhadap kualitas pembelajaran IPA di sekolah sebagai sarana penelitian adalah model pembelajaran berbasis inkuiri.

Dari uraian tersebut di atas, menandakan bahwa proses pembelajaran IPA di SMP Negeri 1 Bulukumba masih rendah ditinjau dari segi kualitasnya. Kualitas proses pembelajaran IPA yang rendah berakibat dari hasil belajar peserta didik yang rendah.

Berdasarkan latar belakang masalah yang telah diuraikan di atas, maka rumusan masalah dalam penelitian ini adalah: (1) Bagaimana mengembangkan perangkat pembelajaran IPA berbasis Inkuiri terbimbing pada materi Asam, Basa, dan Garam? (2) Bagaimana kevalidan, kepraktisan, dan keefektifan perangkat pembelajaran IPA berbasis Inkuiri yang dikembangkan?

Berdasarkan rumusan masalah di atas, maka tujuan dari penelitian ini adalah: (1) Untuk menghasilkan perangkat pembelajaran IPA berbasis Inkuiri Terbimbing pada materi Asam, Basa, dan Garam. (2) Untuk mendeskripsikan kevalidan, keefektifan, dan kepraktisan perangkat pembelajaran IPA berbasis inkuiri terbimbing

\section{METODE PENELITIAN}

Penelitian ini adalah penelitian pengembangan (Research and Development) 
yang bertujuan untuk mengembangkan dan mendesain perangkat pembelajaran IPA berbasis Inkuiri untuk menumbuhkan keterampilan berpikir kritis peserta didik pada materi Asam, Basa, dan Garam yang meliputi Rencana Pelaksanaan Pembelajaran (RPP), Buku Peserta Didik (BPD), dan Lembar Kegiatan Peserta Didik (LKPD).

Penelitian ini dilaksanakan di SMP Negeri 1 Bulukumba dan subyek ujicoba penelitian adalah peserta didik kelas VII-2 semester genap tahun pelajaran 2015/2016 dengan jumlah peserta didik 34 orang.

Pengembangan

perangkat pembelajaran menggunakan model Thiagarajan yang dikenal dengan $4 \mathrm{D}$, yaitu define (pendefinisian), design (perancangan), develop (pengembangan) dan disseminate (penyebaran).

Instrumen penelitian digunakan untuk memperoleh informasi tentang pembelajaran IPA berbasis inkuiri pada materi Asam, Basa, dan Garam. Instrumen pada penelitian ini terdiri dari Komponenkomponen yaitu kevalidan, kepraktisan, dan keefektifan. Berikut ini dikemukakan tentang data yang akan diperoleh dengan menggunakan instrumen-instrumen tersebut: (1) lembar validasi perangkat pembelajaran, (2) lembar observasi keterlaksanaan perangkat pembelajaran, (3) lembar observasi aktivitas peserta didik, (4) lembar angket respon peserta diidk, (5) lembar angket respon guru, (6) lembar penilaian hasil belajar.

Analisis data pada pengembangan perangkat pembelajaran ini, digunakan teknik analisis statistik deskriptif.

\section{HASIL DAN PEMBAHASAN}

\section{Hasil Penelitian}

a. Deskripsi Hasil Tahap

\section{Pengembangan (develop)}

Hasil dari setiap kegiatan pada tahap pengembangan ini diuraikan sebagai berikut.

\section{Analisis Hasil Penilaian Ahli}

Analisis hasil validasi perangkat pembelajaran dapat dideskripsikan sebagai berikut: a). Rencana Pelaksanaan Pembelajaran (RPP)

Hasil analisis validasi RPP untuk setiap aspek sebagaimana pada lampiran C yang dirangkum sebagaimana tertera pada Tabel 4.2:

Tabel 4.2 Rangkuman Hasil Analisis Validasi RPP

\begin{tabular}{|c|c|c|c|}
\hline No & Aspek penilaian & $\bar{x}$ & Ket \\
\hline 1 & Kesesuaian Tujuan & 3,38 & Sangat \\
\hline 2 & $\begin{array}{l}\text { Materi yang } \\
\text { disajikan }\end{array}$ & 3,50 & $\begin{array}{l}\text { Valid } \\
\text { Sangat }\end{array}$ \\
\hline 3 & Bahasa & 3,75 & Valid \\
\hline 4 & $\begin{array}{l}\text { Sarana dan alat } \\
\text { bantu }\end{array}$ & 3,50 & $\begin{array}{l}\text { Sangat } \\
\text { Valid }\end{array}$ \\
\hline 5 & $\begin{array}{l}\text { pembelajaran } \\
\text { Metode dan } \\
\text { kegiatan }\end{array}$ & 3,42 & $\begin{array}{l}\text { Sangat } \\
\text { Valid } \\
\text { Valid }\end{array}$ \\
\hline 6 & $\begin{array}{l}\text { pembelajaran } \\
\text { Waktu }\end{array}$ & 4,00 & $\begin{array}{l}\text { Sangat } \\
\text { Valid }\end{array}$ \\
\hline & Jumlah & 21,55 & \\
\hline & Rata-rata & 3,59 & $\begin{array}{c}\text { Sangat } \\
\text { Valid }\end{array}$ \\
\hline & $\begin{array}{c}\text { Persentase of } \\
\text { Agreement } \\
\text { (Kategori) }\end{array}$ & 100,00 & Reliabel \\
\hline
\end{tabular}

Berdasarkan Tabel 4.2 , hasil analisis validasi RPP menunjukkan bahwa: (1) keseluruhan aspek RPP dinilai sangat valid dan (2) RPP tersebut tergolong reliabel karena nilai reliabilitasnya sama dengan $100 \%$, ini sesuai dengan syarat reliabilitas (Grinnel dalam Nurdin). Dengan demikian, perangkat RPP telah memenuhi kriteria kevalidan. Validator juga menyimpulkan bahwa RPP dapat digunakan dengan revisi kecil.

Walaupun secara keseluruhan aspek, maupun masing-masing aspek sudah memenuhi kriteria kevalidan dan reliabilitas, namun masih ada saran dari validator yang perlu diperhatikan. Saran tersebut adalah sebagai berikut: (1) Alokasi Waktu disesuaikan dengan penambahan aktivitas (V2) (2) Materi pembelajaran diuraikan lengkap pada BPD.(V2)

Berdasarkan saran dan komentar validator maka dilakukan revisi dan penyempurnaan terhadap perangkat RPP. 
Adapun revisi RPP tersebut dapat dilihat pada Tabel 4.3 :

Tabel 4.3 Hasil Revisi RPP

\begin{tabular}{lll}
\hline Yang direvisi & \multicolumn{1}{c}{$\begin{array}{c}\text { Sebelum } \\
\text { revisi }\end{array}$} & Setelah revisi \\
\hline Alokasi & Fase & Fase \\
waktu & penguatan & penguatan \\
disesuaikan & dan & dan \\
dengan & membuat & merangkum \\
aktivitas & rangkuman & di kegiatan \\
& di kegiatan & penutup \\
& penutup & (waktu \\
& (waktu & kegiatan \\
& kegiatan & penutup \\
& penutup & bertambah 3 \\
& menit) & menit \\
& & sehingga \\
& & menjadi 10 \\
& & menit. \\
\hline Uraian materi & Uraian & Uraian \\
Pembelajara & materi & materi \\
& terlalu padat & dipersempit \\
& & karena \\
& & uraian \\
& & lengkap \\
& & terdapat pada \\
& & Buku Peserta \\
& & Didik (BPD) \\
\hline
\end{tabular}

b) Buku Ajar Peserta Didik (BAPD)

Aspek-aspek yang diperhatikan dalam memvalidasi buku ajar peserta didik adalah: penjabaran konsep, konstruksi, karakteristik sub konsep, manfaat/kegunaan buku. Hasil analisis validasi buku ajar peserta didik untuk setiap aspek sebagaimana pada lampiran yang dirangkum pada Tabel 4.4.

Tabel 4.4. Rangkuman Hasil Analisis Validasi Buku Ajar Peserta Didik

\begin{tabular}{c|l|c|c}
\hline No & Aspek penilaian & $\bar{x}$ & Ket \\
\hline $\mathbf{1}$ & Penjabaran & 3,75 & Sangat \\
$\mathbf{2}$ & konsep & 3,44 & Valid \\
$\mathbf{3}$ & Konstruksi & 3,50 & Valid \\
$\mathbf{4}$ & Karakteristik & 3,75 & Sangat \\
& sub konsep & & Valid \\
& & & Sangat \\
& Manfaat/kegunaan & & Valid \\
& buku & & \\
& & & \\
\hline
\end{tabular}

\begin{tabular}{c|c|c|c}
\hline Jumlah & 14,44 & \\
\hline Rata-rata & $\mathbf{3 , 6 1}$ & $\begin{array}{c}\text { Sangat } \\
\text { Valid } \\
\text { Reliabel }\end{array}$ \\
$\begin{array}{c}\text { Persentase of } \\
\text { Agreement } \\
\text { (Kategori) }\end{array}$ & $\mathbf{1 0 0 , 0 0}$ & Reriab \\
\hline
\end{tabular}

Berdasarkan Tabel 4.4, hasil analisis validasi buku ajar peserta didik menunjukkan bahwa: (1) Keseluruhan aspek buku teks pelajaran dinilai sangat valid dan (2) Buku ajar tersebut tergolong reliabel karena nilai reliabilitasnya $100 \%$, ini sesuai dengan syarat reliabilitas (Grinnel dalam Nurdin). Validator juga menyimpulkan bahwa buku ajar peserta didik dapat digunakan dengan revisi kecil.

Walaupun secara keseluruhan aspek, maupun masing-masing aspek sudah memenuhi kriteria kevalidan dan reliabilitas, namun masih ada saran dari validator yang perlu diperhatikan. Saran tersebut adalah : "Gambar diperjelas dengan memberi keterangan".

Berdasarkan saran dan komentar validator maka dilakukan revisi dan penyempurnaan terhadap perangkat buku ajar peserta didik. Adapun hasil revisi buku ajar peserta didik dapat dilihat pada Tabel 4.5 .

Tabel 4.5 Hasil Revisi Buku Ajar Peserta Didik

\begin{tabular}{|c|c|c|}
\hline $\begin{array}{l}\text { Hal Yang } \\
\text { direvisi }\end{array}$ & $\begin{array}{l}\text { Sebelum } \\
\text { revisi }\end{array}$ & Setelah revisi \\
\hline $\begin{array}{l}\text { Validator } \\
\mathbf{1} \\
\text { Gambar }\end{array}$ & $\begin{array}{l}\text { gambar yang } \\
\text { diberikan } \\
\text { tidak } \\
\text { dilengkapi } \\
\text { dengan } \\
\text { keterangan. }\end{array}$ & $\begin{array}{l}\text { Gambar } \\
\text { sudah } \\
\text { dilengkapi } \\
\text { dengan } \\
\text { keterangan }\end{array}$ \\
\hline
\end{tabular}

c) Lembar Kerja Peserta Didik (LKPD) Aspek-aspek yang diperhatikan dalam memvalidasi Lembar Kerja Peserta Didik (LKPD) adalah aspek aktivitas, materi yang disajikan, bahasa, dan waktu.. Hasil analisis 
validasi LKPD sebagaimana pada lampiran dapat dirangkum pada Tabel 4.6. :

Tabel 4.6. Rangkuman Hasil Analisis Validasi LKPD

\begin{tabular}{cccc}
\hline No & $\begin{array}{c}\text { Aspek } \\
\text { penilaian }\end{array}$ & $\begin{array}{c}\text { Rata- } \\
\text { rata }\end{array}$ & Ket \\
\hline 1 & Aktivitas & 3,60 & Sangat \\
2 & Materi & 3,36 & Valid \\
3 & yang disajikan & 3,43 & Valid \\
4 & Bahasa & 3,50 & Valid \\
& Waktu & & Sangat \\
& & & Valid \\
\hline & Jumlah & 14,39 & \\
\hline & Rata-rata total & $\mathbf{3 , 4 7}$ & Valid \\
\hline & Persentase of & $\mathbf{1 0 0 , 0 0}$ & Reliabel \\
& Agreement & & \\
(Kategori) & &
\end{tabular}

Berdasarkan Tabel 4.6, hasil analisis validasi LKPD menunjukkan bahwa: keseluruhan aspek LKPD dinilai valid dan (2) LKPD tersebut tergolong reliabel karena persentase of agreement $(R)$ adalah $100 \%$, ini sesuai dengan syarat reliabilitas (Grinnel dalam Nurdin). Validator juga menyimpulkan bahwa LKPD dapat digunakan dengan revisi kecil.

Walaupun hasil akhir dari validasi untuk lembar kerja peserta didik menunjukkan bahwa para validator umumnya menyimpulkan bahwa lembar kerja yang dikembangkan valid dan dapat digunakan dengan melakukan revisi kecil, tapi masih ada saran dari validator demi untuk kesempurnaan lembar kerja sebelum dilakukan uji coba. Hasil revisi berdasarkan masukan, koreksi, dan saran-saran dari validator sebagaimana pada Tabel 4.7. berikut ini :

Tabel 4.7 Hasil Revisi Lembar Kerja Peserta Didik

\begin{tabular}{lll}
\multicolumn{1}{c}{$\begin{array}{c}\text { Hal yang } \\
\text { Direvisi }\end{array}$} & \multicolumn{1}{c}{$\begin{array}{c}\text { Sebelum } \\
\text { Revisi }\end{array}$} & Setelah Revisi \\
\hline Validator 2 & Pada fase & Sudah \\
Alokasi & kegiatan & dicantumkan \\
waktu & pengamatan & alokasi \\
& tidak & waktunya \\
& dicantumkan & \\
& alokasi waktu & \\
\hline
\end{tabular}

Analisis hasil validasi instrument penelitian dideskripsikan sebagai berikut:

1). Lembar Observasi Keterlaksanaan Pembelajaran

Aspek-aspek yang diperhatikan dalam memvalidasi lembar observasi keterlaksanaan pembelajaran adalah aspek tujuan, aspek cakupan unsure-unsur pembelajaran, dan bahasa. Hasil analisis validasi lembar observasi keterlaksanaan pembelajaran sebagaimana pada lampiran dapat dirangkum pada Tabel 4.8.

Tabel 4. 8 Rangkuman Hasil Analisis Validasi Lembar Observasi Keterlaksanaan Pembelajaran

\begin{tabular}{|c|c|c|c|}
\hline No & Aspek & $\begin{array}{l}\text { Rata- } \\
\text { rata }\end{array}$ & Keterangan \\
\hline 1 & Tujuan & 3,50 & Sangat Valid \\
\hline & $\begin{array}{l}\text { Cakupan unsur- } \\
\text { unsur }\end{array}$ & & \\
\hline 2 & pembelajaran & 3.50 & Sangat Valid \\
\hline \multirow[t]{4}{*}{3} & Bahasa & 3,67 & Sangat Valid \\
\hline & Jumlah & 10,67 & \\
\hline & Rata-rata total & 3,56 & Sangat Valid \\
\hline & $\begin{array}{l}\text { Persentase of } \\
\text { agreement } \\
\text { (Kategori) }\end{array}$ & 100,00 & Reliabel \\
\hline
\end{tabular}

Berdasarkan Tabel 4.8, hasil analisis validasi lembar observasi keterlaksanaan pembelajaran menunjukkan bahwa: (1) keseluruhan aspek dinilai " sangat valid", (2) lembar observasi keterlaksanaan pembelajaran tersebut tergolong reliabel karena semua aspek nilai reliabilitasnya yaitu $100 \%$, ini sesuai dengan syarat reliabilitas (Grinnel dalam Nurdin).

2) Lembar penilaian hasil belajar

Aspek-aspek yang diperhatikan dalam memvalidasi lembar penilaian hasil belajar (LPHB) adalah aspek Materi soal, konstruksi, dan bahasa. Hasil analisis validasi penilaian hasil belajar sebagaimana pada lampiran dapat dirangkum pada Tabel 4.9 di bawah ini:

Tabel 4. 9 Rangkuman hasil analisis validasi $\mathrm{LPHB}$ 


\begin{tabular}{|c|c|c|c|}
\hline No & Aspek & $\begin{array}{c}\text { Rata- } \\
\text { rata }\end{array}$ & Keterangan \\
\hline 1 & Materi soal & 3,30 & Valid \\
\hline 2 & Konstruksi & 3.38 & Valid \\
\hline \multirow[t]{4}{*}{3} & Bahasa & 3,50 & Sangat Valid \\
\hline & Jumlah & 10,16 & \\
\hline & $\begin{array}{c}\text { Rata-rata } \\
\text { total }\end{array}$ & 3,39 & Valid \\
\hline & $\begin{array}{c}\text { Persentase of } \\
\text { agreement } \\
\text { (Kategori) }\end{array}$ & 100,00 & Reliabel \\
\hline
\end{tabular}

Berdasarkan Tabel 4.9, hasil analisis validasi LPHB menunjukkan bahwa (1) keseluruhan aspek dinilai " valid", (2) LPHB tersebut tergolong reliabel karena semua aspek nilai reliabilitasnya yaitu $100 \%$, ini sesuai dengan syarat reliabilitas (Grinnel dalam Nurdin). Walaupun hasil akhir dari validasi untuk penilaian hasil belajar menunjukkan bahwa para validator umumnya menyimpulkan bahwa penilaian hasil belajar yang dikembangkan valid dan dapat digunakan dengan sedikit revisi revisi, tapi masih ada saran dari validator demi untuk kesempurnaan penilaian hasil belajar sebelum dilakukan uji coba. Hasil revisi berdasarkan masukan, koreksi, dan saransaran dari validator sebagaimana pada Tabel 4.10 .

Tabel 4.10 Hasil Revisi Lembar Penilaian Hasil Belajar

\begin{tabular}{lll}
\hline \multicolumn{1}{c}{ Hal yang } & \multicolumn{1}{c}{$\begin{array}{c}\text { Sebelum } \\
\text { Direvisi }\end{array}$} & Sevisi \\
\hline Validator 2 & & \\
Jumlah butir & $\begin{array}{l}\text { Terdiri dari 10 } \\
\text { boutir soal }\end{array}$ & $\begin{array}{l}\text { Terdiri dari } 8 \\
\text { butir soal }\end{array}$ \\
disesuaikan & & \\
dengan & & \\
alokasi & & \\
waktunya & & \\
\hline
\end{tabular}

3) Lembar Observasi Aktivitas Peserta Didik

Aspek-aspek yang diperhatikan dalam memvalidasi lembar observasi aktivitas peserta didik adalah aspek petunjuk, aspek cakupan aktivitas, dan bahasa.. Hasil analisis validasi lembar observasi aktivitas peserta didik sebagaimana pada lampiran dapat dirangkum pada Tabel 4.11.

Tabel 4. 11 Rangkuman Hasil Analisis Validasi Lembar Observasi Aktivitas Peserta Didik

\begin{tabular}{cccc}
\hline No & Aspek & $\begin{array}{c}\text { Rata- } \\
\text { rata }\end{array}$ & Keterangan \\
\hline 1 & Petunjuk & 3,50 & Sangat Valid \\
& $\begin{array}{c}\text { Cakupan } \\
\text { aktivitas }\end{array}$ & 3.50 & Sangat Valid \\
3 & Bahasa & 3,50 & Sangat Valid \\
\hline & Jumlah & 10,50 & \\
\hline & Rata-rata total & $\mathbf{3 , 5 0}$ & Sangat Valid \\
\hline & $\begin{array}{c}\text { Persentase of } \\
\text { agreement } \\
\text { (Kategori) }\end{array}$ & $\mathbf{1 0 0 , 0 0}$ & Reliabel \\
\hline
\end{tabular}

Berdasarkan Tabel 4.11, hasil analisis validasi lembar aktivitas peserta didik menunjukkan bahwa (1) keseluruhan aspek dinilai "sangat valid", (2) lembar observasi aktivitas peserta didik tersebut tergolong reliabel karena semua aspek nilai reliabilitasnya yaitu $100 \%$, ini sesuai dengan syarat reliabilitas (Grinnel dalam Nurdin).

4) Respon peserta didik dan guru

Aspek-aspek yang diperhatikan dalam memvalidasi lembar observasi respon peserta didik adalah aspek materi, aspek konstruksi, dan bahasa.. Hasil analisis validasi lembar observasi respon peserta didik sebagaimana pada lampiran dapat dirangkum pada Tabel 4.12.

Tabel 4. 12 Rangkuman Hasil Analisis Validasi Lembar Observasi Respon Peserta Didik dan Guru

\begin{tabular}{|c|c|c|c|c|}
\hline \multirow[t]{2}{*}{$\begin{array}{l}\mathrm{N} \\
\mathrm{O}\end{array}$} & \multirow[t]{2}{*}{ Aspek } & \multicolumn{2}{|c|}{$\begin{array}{c}\text { Rata-rata } \\
\text { Respon }\end{array}$} & Keterangan \\
\hline & & $\begin{array}{c}\text { Pesert } \\
\text { a } \\
\text { didik }\end{array}$ & Guru & \\
\hline 1 & Materi & 3,50 & 3,50 & $\begin{array}{l}\text { Sangat } \\
\text { Valid }\end{array}$ \\
\hline 2 & $\begin{array}{l}\text { Konstruk } \\
\text { si }\end{array}$ & 3.50 & 3,50 & $\begin{array}{l}\text { Sangat } \\
\text { Valid }\end{array}$ \\
\hline
\end{tabular}




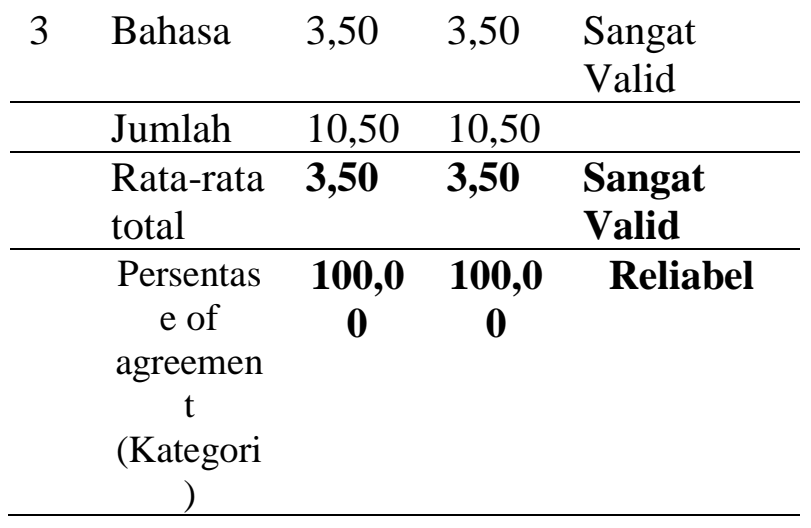

Berdasarkan Tabel 4.12, hasil analisis validasi lembar respon peserta didik dan guru menunjukkan bahwa (1) keseluruhan aspek dinilai " sangat valid", (2) lembar observasi respon peserta didik dan guru tersebut tergolong reliabel karena semua aspek nilai reliabilitasnya yaitu $100 \%$, ini sesuai dengan syarat reliabilitas (Grinnel dalam Nurdin).

Berdasarkan uraian di atas dapat disimpulkan bahwa secara umum rata-rata penilaian atau hasil validasi dari dua orang validator pada perangkat pembelajaran berupa RPP dan BPD yang digunakan berada pada kategori "sangat valid", dan Lembar kerja Peserta Didik (LKPD) berada pada kategori " Valid". Demikian pulan hasil validasi pada instrumen penelitian berupa lembar observasi keterlaksanaan pembelajaran, lembar observasi aktivitas peserta didik, dan lembar angket respon peserta didik dan guru berada pada kategori "Sangat Valid" dan lembar penilaian hasil belajar berada pada kategori "Valid". Hal ini berarti perangkat pembelajaran maupun instrumen pembelajaran tersebut telah layak untuk diujicobakan.

Akhirnya setelah dilakukan beberapa revisi berdasarkan masukan dari validator dihasilkan perangkat pembelajaran (Prototipe II), yang digunakan pada kegiatan uji coba.

\section{b. Analisis Hasil Ujicoba Lapangan}

Perangkat Pembelajaran yang telah direvisi berdasarkan masukan dari para validator selanjutnya diujicobakan di kelas $\mathrm{VII}_{2}$ SMP Negeri 1 Bulukumba dengan jumah peserta didik 34 orang. Pada kegiatan ini peneliti terlibat langsung pada proses pembelajaran. Perangkat pembelajaran yang di ujicobakan meliputi RPP, Buku peserta didik, dan LKPD. Uji coba perangkat pembelajaran bertujuan untuk penyempurnaan perangkat pembelajaran. Adapun rincian pelaksanan uji coba dirangkum dalam tabel 4.13

Tabel 4. 13. Jadwal Pelaksanaan Uji Coba Perangkat Pembelajaran

\begin{tabular}{|c|c|c|c|c|}
\hline \multirow[t]{2}{*}{$\begin{array}{l}\text { Pertem } \\
\text { uan }\end{array}$} & \multirow[t]{2}{*}{$\begin{array}{c}\text { Hari/Ta } \\
\text { nggal }\end{array}$} & \multicolumn{3}{|c|}{$\begin{array}{c}\text { Uji coba Perangkat } \\
\text { Pembelajaran }\end{array}$} \\
\hline & & $\begin{array}{l}\mathrm{R} \\
\mathrm{P} \\
\mathrm{P}\end{array}$ & $\begin{array}{l}\mathrm{L} \\
\mathrm{K} \\
\mathrm{S}\end{array}$ & $\begin{array}{l}\text { Buku } \\
\text { siswa }\end{array}$ \\
\hline $\begin{array}{l}\text { I } \\
\text { II } \\
\text { III }\end{array}$ & $\begin{array}{c}\text { Rabu, } \\
13-4- \\
2016 \\
\text { Kamis, } \\
14-4- \\
2016 \\
\text { Rabu, } \\
20-4- \\
2016\end{array}$ & $\begin{array}{l}\mathrm{R} \\
\mathrm{P} \\
\mathrm{P} \\
0 \\
1 \\
\mathrm{R} \\
\mathrm{P} \\
\mathrm{P} \\
0 \\
2 \\
\mathrm{R} \\
\mathrm{P} \\
\mathrm{P} \\
0 \\
3\end{array}$ & $\begin{array}{c}\text { LK } \\
\text { S } \\
01 \\
\text { LK } \\
\text { S } \\
02 \\
\text { LK } \\
\text { S } \\
03\end{array}$ & $\begin{array}{l}\text { Pembela } \\
\text { jaran } 01 \\
\text { Pembela } \\
\text { jaran 01 } \\
\text { Pembela } \\
\text { jaran } 03\end{array}$ \\
\hline IV & $\begin{array}{c}\text { Kamis, } \\
21-04- \\
2016\end{array}$ & \multicolumn{3}{|c|}{ Tes Hasil Belajar } \\
\hline V & $\begin{array}{c}\text { Rabu, } \\
04-05- \\
2016\end{array}$ & \multicolumn{3}{|c|}{$\begin{array}{l}\text { Pengisisan angket } \\
\text { respon Peserta didik }\end{array}$} \\
\hline
\end{tabular}

Peserta didik yang menjadi subjek uji coba perangkat ini adalah peserta didik Kelas VII 2 SMP Negeri 1 Bulukumba, semester genap tahun pelajaran 2015/2016. Dengan jumlah peserta didik sebanyak 34 orang dengan kemampuan akademik yang beragam, ada peserta didik yang berkemampuan tinggi, sedang, dan rendah. Dalam proses pembelajaran, peserta didik dikelompokkan 4 atau 5 orang dalam satu kelompok, yang terdiri dari 1 atau 2 orang peserta didik kelompok atas, 1 atau 2 orang peserta didik kelompok tengah, dan 1 orang peserta didik kelompok bawah. Pembagian kelompok didasarkan dari rata-rata nilai 
ulangan harian, serta keaktifan peserta didik dalam pembelajaran IPA selama di kelas VII. Dengan demikian, dapat dikatakan bahwa kemampuan rata-rata tiap kelompok relatif sama. Guru dalam penelitian ini adalah peneliti sendiri.

Deskripsi hasil ujicoba perangkat pembelajaran dilakukan sebanyak 4 kali pertemuan mulai tanggal 13 April 2016 sampai 4 Mei 2016, yaitu 3 kali pertemuan untuk KBM, 1 kali tes hasil belajar dan 1 kali pengisian angket respon terhadap perangkat pembelajaran. Pengisian angket respon peserta didik dilaksanakan setelah uji coba perangkat dilakukan. Rancangan awal perangkat pembelajaran (Prorotipe I) divalidasi oleh ahli. Hasil validasi ahli dijadikan sebagai bahan pertimbangan untuk merevisi perangkat pembelajaran yang menghasilkan Prototipe II, kemudian diujicobakan di kelas $\mathrm{VII}_{2}$ SMP Negeri 1 Bulukumba.

Data yang diperoleh saat uji coba dianalisis, kemudian hasilnya digunakan sebagai bahan pertimbangan untuk merevisi Prototipe II menjadi perangkat final

yang selanjutnya akan disosialisasikan pada proses penyebaran..Berikut adalah gambaran data yang diperoleh dari hasil uji coba berupa data keterlaksanaan perangkat pembelajaran, data aktivitas peserta didik, data tes hasil belajar, data respons peserta didik, dan data respon guru.

\section{1) Uji kepraktisan (keterlaksanaan) perangkat pembelajaran}

a) Deskripsi hasil analisis keterlaksanaan perangkat pembelajaran

Tujuan utama analisis data keterlaksanaan perangkat pembelajaran adalah untuk melihat sejauh mana tingkat kepraktisan penggunaan perangkat dalam proses pembelajaran. Dalam mengobservasi keterlaksanaan perangkat, peneliti menggunakan dua orang guru mitra sebagai pengamat pada setiap pertemuan, selanjutnya untuk memberikan penekanan bahwa lembar keterlaksanaan pembelajaran memenuhi reliabilita $\mathrm{s}$ maka, dihitung reliabilitas lembar pengamatan keterlaksanaan perangkat tersebut dengan menggunakan hasil modifikasi rumus percentage of agreements Grinnel (Nurdin, 2007 : 145) sebagai berikut:

Percentage of agreement $(R)=$ Agreements (A)

Disagreements (D) $+\operatorname{agreement}(\mathrm{A})$ $100 \%$

dengan:

$A=$ Jumlah frekuensi kecocokan antara, dua pengamat

$D=$ Jumlah frekuensi ketidakcocokan antara dua pengamat

$\mathrm{R}=$ Reliabilitas instrumen Agar lebih mudah menarik kesimpulan, maka data pengamatan keterlaksanaan perangkat pembelajaran dianalisis per aspek. Adapun hasil analisis untuk masing-masing aspek dijelaskan sebagai berikut:

1) Komponen sintaks pembelajaran inkuiri terbimbing. Hasil pengamatan terhadap keterlaksanaan komponen sintaks pembelajaran inkuiiri terbimbing selama uji coba dapat dilihat pada Tabel 4.14.

Tabel 4.14. Hasil Pengamatan Keterlaksanaan Komponen Sintaks Pembelajaran Inkuiri Terbimbing

\begin{tabular}{llllllll}
\hline & & Aspek & \multicolumn{5}{c}{ Hasil Pengamatan } \\
\cline { 2 - 7 } No & Pengamatan & A & B & A & B & A & B \\
& & &
\end{tabular}

Fase

penyampaian

1 tujuan pembelajaran dan $\begin{array}{lllllll}1 & 2 & 2 & 2 & 2 & 2\end{array}$ memotivasi peserta didik;

$\begin{array}{llllllll}2 & \text { Fase Orientasi; } & 2 & 2 & 2 & 2 & 2 & 2\end{array}$

Fase membimbing peserta didik dalam $\begin{array}{llllll}2 & 2 & 2 & 2 & 2 & 2\end{array}$ merumuskan masalah;

Fase membimbing

4 peserta didik $2 \begin{array}{llllll}2 & 2 & 2 & 2 & 2 & 2\end{array}$ dalam merumuskan 
hipotesis;

Fase

membimbing

peserta didik

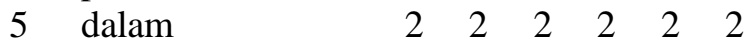

mengumpulkan

data melalui

eksperimen

Fase

membimbing

peserta didik

6. dalam $\quad 2 \quad 2 \quad 2 \quad 2 \quad 2 \quad 2 \quad 2$

menganalisis data

untuk menguji

hipotesis

7. $\begin{array}{lllllll}\text { Fase merumuskan } & 2 & 2 & 2 & 2 & 2 & 2\end{array}$

\begin{tabular}{cccc}
\hline Agreement & 7 & 7 & 7 \\
\hline Disagreement & 0 & 0 & 0 \\
\hline Rata-rata pengamatan & 1,93 & 2,00 & 2,00
\end{tabular}

Tabel 4.14 menunjukkan bahwa jumlah agreement dua pengamat adalah 21 dan disagreement adalah 0 , berarti dua pengamat sepakat bahwa Komponen Sintaks pembelajaran IPA berbasis Inkuiri Terbimbing terlaksana dengan percentage of agreement $(\mathrm{PA})=100 \%$. Jika dikonfirmasi dengan kriteria keterlaksanaan pada bab III, maka disimpulkan Komponen sintaks pembelajaran berbasis Inkuiri Terbimbing terlaksana seluruhnya $(1,5 \leq \bar{x} \leq 2,0)$.

2). Interaksi sosial. Hasil pengamatan terhadap keterlaksanaan komponen interaksi sosial selama uji coba dapat dilihat pada Tabel 4.15.berikut:

Tabel 4.15. Hasil Pengamatan Keterlaksanaan Komponen Interaksi Sosial

\begin{tabular}{|c|c|c|c|c|c|c|}
\hline \multirow{3}{*}{ No } & \multirow{3}{*}{$\begin{array}{c}\text { Aspek } \\
\text { Pengamatan }\end{array}$} & \multicolumn{5}{|c|}{ Hasil Pengamatan } \\
\hline & & $\begin{array}{l}\text { Pert. } \\
1\end{array}$ & \multicolumn{2}{|c|}{$\begin{array}{l}\text { Pert. } \\
2\end{array}$} & \multicolumn{2}{|c|}{$\begin{array}{l}\text { Pert. } \\
3\end{array}$} \\
\hline & & A $\quad$ B & $\mathrm{A}$ & $\mathrm{B}$ & A & $\mathrm{B}$ \\
\hline 1. & $\begin{array}{l}\text { Interaksi antara } \\
\text { guru dan peserta } \\
\text { didik, serta } \\
\text { peserta didik dan } \\
\text { peserta didik. }\end{array}$ & 21 & 2 & 2 & 2 & 2 \\
\hline
\end{tabular}

2. Keaktifan peserta didik dalam melakukan

aktivitas untuk menemukan konsep pembelajaran yang sesuai dengan petunjuk pada buku peserta didik dan LKPD

$\begin{array}{llllllll}3 & \text { Keaktifan peserta } & 1 & 2 & 2 & 2 & 2 & 2\end{array}$ didik dalam menyelesaikan masalah yang terdapat pada

LKPD.

$\begin{array}{llllllll}4 & \text { Keaktifan peserta } & 1 & 2 & 2 & 1 & 2 & 1\end{array}$ didik dalam belajar khususnya pada saat peserta didik mengkonstruksi pengetahuan dan menyelesaikan LKPD.

\begin{tabular}{cccc}
\hline Agreement & 4 & 4 & 4 \\
\hline Disagreement & 0 & 0 & 0 \\
\hline Rata-rata & 1.63 & 1.75 & 1,88 \\
\hline
\end{tabular}

Tabel 4.15 menunjukkan bahwa jumlah agreement dua pengamat adalah 12 dan disagreement adalah 0 , rata-rata pengamatan 1,75 berarti dua pengamat sepakat bahwa Komponen interaksi sosial terlaksana dengan percentage of agreement $(\mathrm{PA})=100 \%$. Jika dikonfirmasi dengan kriteria keterlaksanaan pada bab III, maka disimpulkan Komponen interaksi sosial terlaksana seluruhnya $(1,5 \leq \bar{x} \leq 2,0)$.

3). Prinsip reaksi. Hasil pengamatan terhadap keterlaksanaan komponen prinsip reaksi selama uji coba dapat dilihat pada Tabel 4.16 berikut:

Tabel 4.16. Hasil Pengamatan Keterlaksanaan Komponen Prinsip Reaksi

\begin{tabular}{ccccc}
\hline & & \multicolumn{3}{c}{ Hasil Pengamatan } \\
\cline { 3 - 5 } $\mathrm{N}$ & Aspek & Pert. & & Pert. \\
$\mathrm{o}$ & Pengamatan & 1 & Pert. & 3 \\
& & & 2 & \\
\hline
\end{tabular}




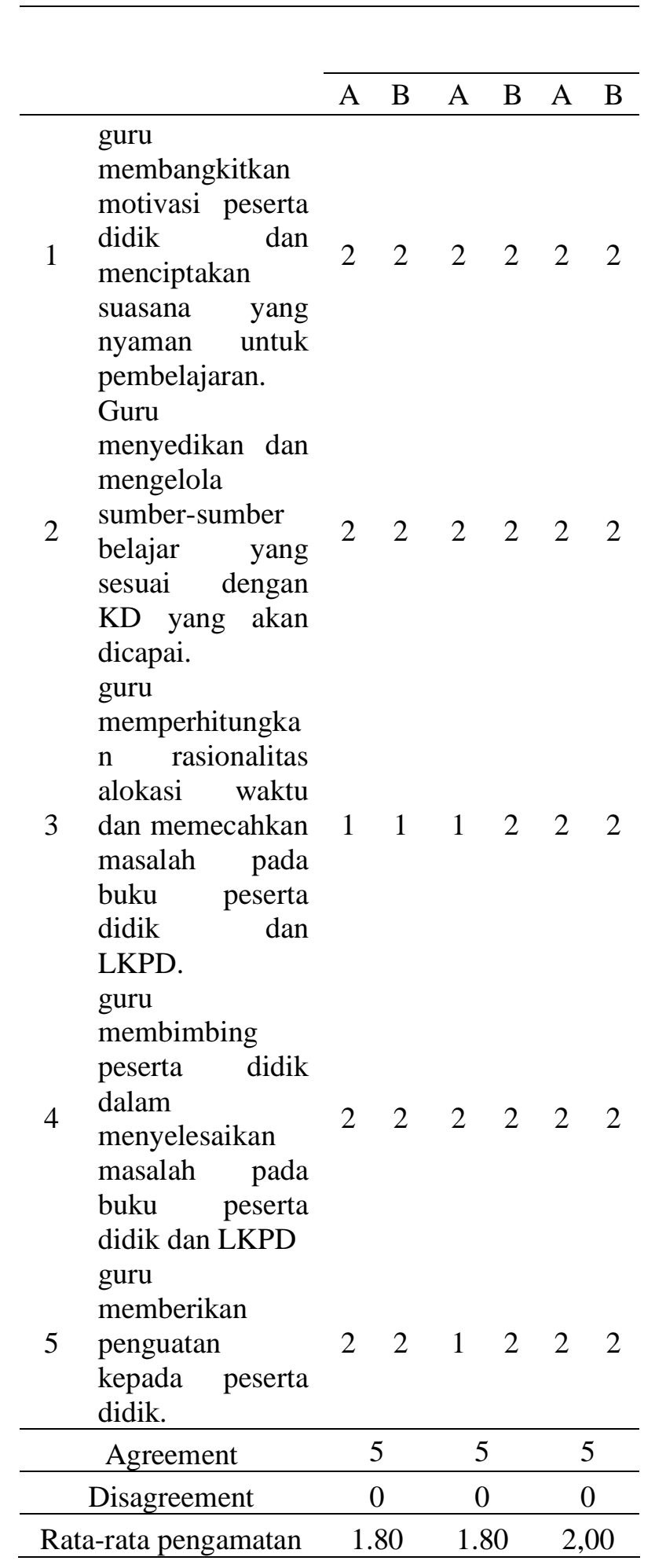

Tabel 4.16 menunjukkan bahwa jumlah agreement dua pengamat adalah 20 dan disagreement adalah 0 dan rata-rata pengamatan 1,87, berarti dua pengamat sepakat bahwa Komponen prinsip reaksi terlaksana dengan percentage of agreement $(\mathrm{PA})=100 \%$. Jika dikonfirmasi dengan kriteria keterlaksanaan maka disimpulkan
Komponen prinsip reaksi terlaksana seluruhnya $(1,5 \leq \bar{x} \leq 2,0)$.

\section{2) Uji pembelajaran \\ keefektifan}

Pada bagian sebelumnya, telah dikemukakan hasil uji kevalidan beserta perangkat-perangkat dan instrumen yang lain. Selanjutnya akan dideskripsikan hasil uji keefektifan. Pada batasan istilah telah dinyatakan bahwa perangkat pembelajaran dikatakan efektif apabila memenuhi 3 dari 4 kriteria keefektifan tetapi kriteria pertama harus dipenuhi.. Kriteria tersebut yaitu : (1) Ketercapaian ketuntasan belajar yaitu minimal $80 \%$ peserta didik mencapai penguasaan perangkat pembelajaran yaitu mencapai nilai minimal 75 (berdasarkan KKM untuk kelas VII SMP Negeri 1 Bulukumba) untuk rentang skor $0-100$, (2) aktivitas peserta didik selama kegiatan belajar memenuhi kriteria toleransi waktu yang telah ditetapkan, (3) untuk respon peserta didik terhadap kegiatan pembelajaran, sekurang-kurangnya $80 \%$ dari peserta didik yang member respon positif

a) Deskripsi penilaian hasil belajar.

Hasil analisis deskriptif skor tes hasil belajar peserta didik setelah pembelajaran dengan menggunakan perangkat pembelajaran IPA berbasis Inkuiri Terbimbing untuk menumbuhkan keterampilan berpikir kritis peserta didik dilihat pada Tabel 4.19.

Tabel 4.19. Statistik Skor Hasil Belajar Peserta Didik pada Materi Asam, Basa, dan Garam Kelas $\mathrm{VII}_{2} \quad$ SMP Negeri 1 Bulukumba

\begin{tabular}{cc}
\hline Variabel & Nilai Statistik \\
\hline Subjek Penelitian & 34 \\
Skor Ideal & 100 \\
Rata-rata & 88,11 \\
Standar Deviasi & 10,00 \\
Rentang Skor & 37
\end{tabular}


Skor Maksimum

100

Skor Minimum

63,00

Tabel 4.19. menunjukkan bahwa nilai rata-rata hasil belajar peserta didik Kelas $\mathrm{VII}_{2}$ SMP Negeri 1 Bulukumba pada materi Asam, Basa, dan Garam adalah rata - rata hasil belajar peserta didik yang diperoleh adalah 88,11 dengan standar deviasi 10,00. nilai tertinggi yakni 100 dan nilai terendah 63 dengan rentang nilai 37. Jika nilai hasil belajar yang ada dikelompokkan ke dalam 5 kategori, maka diperoleh distribusi frekuensi seperti pada Tabel 4.20.

Tabel 4.20. Distribusi Frekuensi dan Persentase Skor Prestasi Hasil Belajar IPA KelasVII 2 SMP Negeri 1 Bulukumba pada Tes Hasil Belajar

\begin{tabular}{cccc} 
Skor & Kategori & Frekuensi & Persentase \\
\hline $0-34$ & $\begin{array}{c}\text { Sangat } \\
\text { Rendah }\end{array}$ & - & $0 \%$ \\
$35-54$ & Rendah & - & $0 \%$ \\
$55-64$ & Sedang & 1 & $2,94 \%$ \\
$65-84$ & Tinggi & 10 & $29,41 \%$ \\
$85-100$ & $\begin{array}{c}\text { Sangat } \\
\text { Tinggi }\end{array}$ & 23 & $67,65 \%$ \\
\hline
\end{tabular}

Tabel 4.20, menunjukkan bahwa dari

34 peserta didik yang mengikuti tes hasil belajar, terdapat $0 \%$ peserta didik yang berada pada kategori sangat rendah, 0\% berada pada kategori rendah, 2,94\% berada pada kategori sedang, $29,41 \%$ peserta didik yang berada pada kategori tinggi, dan $67,65 \%$ peserta didik berada pada kategori sangat tinggi. Nilai rata-rata hasil belajar IPA peserta didik Kelas VII $_{2}$ SMP Negeri 1 Bulukumba adalah 88,11 dari nilai ideal 100 berada pada interval 85 - 100. Dengan demikian, dapat disimpulkan bahwa ratarata nilai hasil belajar IPA peserta didik Kelas $\mathrm{VII}_{2}$ SMP Negeri 1 Bulukumba berada pada kategori "Sangat Tinggi".

Apabila hasil belajar peserta didik dianalisis maka persentase ketuntasan hasil belajar peserta didik setelah diterapkan perangkat pembelajaran IPA berbasis Inkuiri
Terbimbing untuk menumbuhkan keterampilan berpikir kritis peserta didik dapat dilihat pada Tabel 4.21.

Tabel 4.21. Deskripsi Ketuntasan Hasil Belajar IPA

\begin{tabular}{cccc}
\hline Nilai & Kategori & Frekuensi & Persentase \\
\hline $0-74$ & Tidak & 4 & $11,77 \%$ \\
$75-100$ & Tuntas & 30 & $88,24 \%$ \\
& Tuntas & & \\
\hline
\end{tabular}

Tabel 4.21. diatas menunjukkan bahwa dari 34 peserta didik terdapat $88,24 \%$ peserta didik yang telah tuntas belajar. Dengan demikian, menurut kriteria pada BAB III, penguasaan tes hasil belajar peserta didik sudah memenuhi standar ketuntasan klasikal.

Selain hasil analisis deskriptif skor tes hasil belajar peserta didik juga dilakukan analisis Pencapaian Keterampilan berpikir Kritis Peserta Didik. Hasil analisis pencapaian keterampilan berpikir kritis dapat dilihat pada tabel 4.22. berikut:

Tabel 4.22. Hasil Analisis Pencapaian Keterampilan Berpikir Kritis

\begin{tabular}{lcccc}
\hline Skor & $\begin{array}{c}\text { Jumlah } \\
\text { peserta } \\
\text { didik }\end{array}$ & Prs & $\begin{array}{c}\text { Nilai } \\
\text { huruf }\end{array}$ & Interpretasi \\
\hline 48 ke & 0 & 0 & a & sangat \\
atas & 17 & 50 & b & tinggi \\
$43-$ & 6 & 17,65 & $\mathrm{c}$ & tinggi \\
47 & 7 & 20,59 & $\mathrm{~d}$ & sedang \\
$39-$ & 4 & 11,76 & $\mathrm{e}$ & $\begin{array}{c}\text { rendah } \\
\text { sangat }\end{array}$ \\
42 & & & & rendah \\
$34-38$ & & & & \\
33 ke & & & & \\
bawah & & & & \\
\hline
\end{tabular}

Berdasarkan hasil analisis

keterampilan berpikir kritis peserta didik dengan menggunakan penilaian skala lima dapat dikatakan bahwa tingkat kemampuan keterampilan berpikir kritis peserta didik berbeda-beda, terdapat $11,76 \%$ kategori sangat rendah, $20,59 \%$ kategori rendah, $17,65 \%$ kategori sedang, $50 \%$ kategori baik.dan tidak terdapat pencapaian keterampilan berpikir kritis dalam kategori sangat tinggi. Hasil pencapaian tersebut tentunya tidak lepas dari tingkat penguasaan indikator berpikir kritis tiap peserta didik. 
Dalam hal ini ada peserta didik yang tingkat pemahamannya tinggi, ada yang sedang dan ada yang rendah secara individu. Hal ini karena tes yang mengacu pada indikatorindikator dari berpikir kritis masih terdapat sebagian peserta didik yang belum memahami/menguasai dengan baik, sehingga secara keseluruhan nilai pada kategori sangat tinggi belum didapatkan.

b). Deskripsi hasil pengamatan aktivitas peserta didik.

Instrumen lembar pengamatan aktivitas peserta didik digunakan untuk mengamati semua aktivitas peserta didik selama kegiatan pembelajaran berlangsung. Pengamatan dilakukan oleh 2 orang observer/pengamat terhadap 1 kelompok peserta didik yang dipilih oleh pengamat dari 7 kelompok yang terbentuk. Pembagian kelompok didasarkan dari rata-rata nilai ulangan harian, serta keaktifan peserta didik dalam pembelajaran IPA selama di kelas VII.

Prosedur pengamatan yang dilakukan adalah setiap 4 menit pengamat melakukan pengamatan terhadap aktivitas peserta didik yang dominan muncul dan 1 menit berikutnya pengamat menuliskan hasil pengamatannya pada lembar yang disediakan. Frekuensi aktivitas peserta didik terangkum pada Tabel 4.23.

Tabel 4.23. Rekapitulasi Aktivitas Peserta Didik

\begin{tabular}{|c|c|c|}
\hline $\begin{array}{c}\text { Aspek Pengamatan } \\
\text { Aktivitas Peserta didik }\end{array}$ & $\begin{array}{c}\text { Rata-rata } \\
\text { Persentase } \\
\text { aktivitas } \\
\text { peserta } \\
\text { didik } \\
\end{array}$ & $\begin{array}{l}\text { Interval } \\
\text { Toleransi } \\
\text { PWI }(\%)\end{array}$ \\
\hline $\begin{array}{l}\text { Aktif memperhatikan } \\
\text { penjelasan guru }\end{array}$ & 17,50 & $13-23$ \\
\hline $\begin{array}{lr}\text { Aktif } & \text { berdiskusi } \\
\text { dengan } & \text { teman }\end{array}$ & & $7-17$ \\
\hline $\begin{array}{l}\text { kelompoknya untuk } \\
\text { merumuskan masalah }\end{array}$ & 11,67 & \\
\hline $\begin{array}{lr}\text { Aktif } & \text { melakukan } \\
\text { kegiatan } & \text { bersama }\end{array}$ & & \\
\hline teman kelompoknya & 18,13 & $13-23$ \\
\hline $\begin{array}{lr}\text { Aktif } & \text { berdiskusi } \\
\text { dengan } & \text { teman }\end{array}$ & & \\
\hline $\begin{array}{lr}\text { kelompoknya } & \text { dalam } \\
\text { menyusun } & \text { konsep }\end{array}$ & 15,21 & $13-23$ \\
\hline
\end{tabular}

terkait materi yang dipelajari.

Meminta bimbingan pada guru jika mengalami kesulitan dalam kelompok Menyajikan dan menanggapi hasil kerja kelompok.

Membuat

rangkuman/kesimpulan Melakukan kegiatan di luar tugas belajar, misalnya mengantuk, ngobrol, tidur, melamun, bermain, dan sebagainya

Berdasarkan Tabel 4.23, terlihat bahwa selama kegiatan pembelajaran IPA berbasis Inkuiri Terbimbing berlangsung, peserta didik telah terlibat secara aktif sehingga dominasi guru dalam pembelajaran dapat berkurang.

\section{KESIMPULAN}

Berdasarkan hasil penelitian dan uji coba perangkat pembelajaran IPA Berbasis Inkuiri Terbimbing pada materi Asam, Basa, dan Garam pada kelas $\mathrm{VII}_{2}$ SMP Negeri 1 Bulukumba diperoleh beberapa kesimpulan sebagai berikut:

1. Pengembangan perangkat pembelajaran pada penelitian ini menggunakan model 4-D yang terdiri dari 4 tahap yaitu pendefinisian (define), perancangan (design), dan pengembangan (develop), dan tahap penyebaran (dessiminate). Adapun langkah-langkah kegiatan pengembangan yang dilakukan oleh peneliti adalah sebagai berikut:

a. Tahap pendefinisian (define); meliputi kegiatan analisi awal-akhir, analisi peserta didik, analisi materi, analisi tugas dan analisis spesifikasi tujuan pembelajaran.

b. Tahap perancangan (design); meliputi kegiatan pemilihan media , pemilihan format dan rancangan awal perangkat pembelajaran (Prototipe I) 
c. Tahap pengembangan(develop); meliputi kegiatan validasi ahli, revisi I (Prototipe II), uji coba perangkat pembelajaran (Prototipe III) sehingga diperoleh hasil pengembangan.

d. Tahap penyebaran (disseminate); meliputi sosialisasi secara terbatas pada guru IPA SMPN 1 Bulukumba.

2. Perangkat pembelajaran yang dihasilkan pada penelitian ini adalah perangkat pembelajaran IPA Berbasis Inkuiri Terbimbing pada materi Asam, Basa, dan Garam untuk peserta didik kelas VII SMP yang terdiri dari:

a. Rencana Pelaksanaan pembelajaran (RPP): RPP yang dihasilkan pada penelitian ini adalah 3 buah RPP untuk 3 pertemuan berisi garis besar tentang hal-hal yang akan dilakukan oleh guru dan peserta didik selama proses pembelajaran berlangsung dengan pembelajaran berbasis Inkuiri Terbimbing

b. Buku Ajar Peserta Didik; Buku ajar peserta didik yang merupakan buku panduan bagi peserta didik dalam kegiatan pembelajaran yang memuat materi pelajaran dan soal latihan

c. Lembar Kerja Peserta Didik (LKPD); Merupakan salah satu jenis alat bantu pembelajaran, yang terdiri dari 3 buah LKPD untuk 3 pertemuan yang berisikan aktivitas penyelidikan berupa petunjuk/ arahan langkahlangkah dalam menemukan konsep, masalah sebagai penerapan dari konsep/prinsip

3. Secara Umum hasil pengembangan perangkat pembelajaran dalam penelitian ini valid, praktis dan efektif. (a) Rancangan Pelaksanaan Pembelajaran (RPP) dan Buku Peserta didik (BPD) "Sangat Valid", Lembar Kerja Peserta Didik (LKPD) dikategorikan "Valid" (b) Praktis, berdasarkan hasil pengamatan oleh observer bahwa perangkat pembelajaran terlaksana dengan baik pada saat uji coba serta memperoleh respon positif terhadap perangkat dan proses pembelajaran dan (c) efektif, telah memenuhi tiga kreteria yaitu ketuntasan belajar secara klasikal tercapai, aktivitas siswa efektif dan respon siswa terhadap pembelajaran positif

\section{DAFTAR PUSTAKA}

Al'Azzy,U.L \& Budiono Eddy.(.....). Penerapan Strategi Brain Bassed Learning yang dapat Meningkatkan Keterampilan Berpikir Tingkat Tinggi. Online. http:// Jurnalonline.um.ac.id/..../artikelID7 E65F5E46C6CBD3E592D38AF9EF O..(diakses pada tanggal 21 Januari 2016)

Apriliyana U, Fitrihidayati H, Rahardjo. (2012). Pengembangan Perangkat Pembelajaran Berbasis Inkuiri pada Materi Pencemaran Lingkungan dalam Upaya Melatih Keterampilan Berpikir Kritis Siswa Kelas X SMA.

Asmuniv.(2015). Pendekatan Inkuiri dan Siklus Belajar sebagai Upaya Meningkatkan Pemahaman Konsep dan Keterampilan Berpikir Kritis. Malang: PPPPTKVEDC.Online.(http://www.Vedcmala ng.com/pppptkboemlg/indeks.php diakses pada tanggal 11 Januari 2016)

Damayanti,D.S, Ngazizah,N, Setyadi K,E. (2012). Pengembangan Lembar Kerja Siswa (LKS) dengan Pendekatan Inkuiri Terbimbing untuk Mengoptimalkan Kemampuan Berpikir Kritis Peserta Didik pada Materi Listrik Dinamis SMA Negeri 3 Purwerejo kelas X Tahun Pelajaran 2012/2013. Online. Radiasi Vol.3.No.1.Dyah Shinta Damayanti. Program Studi Pendidikan Fisika Universitas Muhammadiyah Purwerejo. (diakses pada tanggal

Depdiknas. 2003. Undang-Undang Republik Indonesi Nomor 20 Tahun 2003. Online.

http://sdm.datakemdikbud.go.id/.../u ndang-undang-no-20- 
entang.sisdiknas.pdf. (diakses pada tanggal 14 Januari 2016)

Depdiknas. 2008. Panduan Pengembangan Bahan ajar. Jakarta: Depertemen Pendidikan Nasional.

Fatmawati,H, Mardiyana, Triyanto. (2013). Analisis Berpikir Kritis Siswa dalam Pemecahan Masalah Matematika Berdasarkan Polya pada Pokok Bahasan Persamaan Kuadrat (penelitian pada Siswa Kelas X SMK Muhammadiyah 1 Sragen Tahun Pelajaran 2013/2014). Online. Jurnal Elektronik Pembelajaran Matematika ISSN: 2339-1685 Vol.2 No.9, hal 899-910, Novemver 2014. http://jurnal fkip.uns.ac.id.

Goldberg D E. 2008. Kimia untuk Pemula. Edisi ketiga. Jakarta: Erlangga

Hadiyanti, L.N. (2013). Keterampilan Berpikir Kritis (Critical ThinkingSkill) dalam Berbagai Deimensi Pembelajaran Biologi. Program Magister Pendidikan Biologi Sekolah Pascasarjana. Universitas Pendidikan Indonesia. Sintesis Jurnal Internasional. Online.(diakses pada tanggal 16 Desember 2015).

Hamalik,O.(2001).

Perencanaan Pengajaran Berdasarkan

Pendekatan Sistem. Bandung: Bumi Aksara.

Herdian. (2010). Model Pembelajaran Inkuiri. Online. http://herdi07.wordpress.com/2010/0 5/07/model-pembelajaraninkuiri.html

Jusmiati Jafar. (2014). Pengaruh Model Pembelajaran Inkuiri pada Mata Pelajaran Biologi terhadap aktivitas, Kemampuan Berpikir Kritis, dan Hasil Belajar Siswa Kelas XI IPA SMAN 1 Alla Kabupaten Enrekang. Tesis. Program Pascasarjana UNM Makassar. Tidak Diterbitkan.

Kemendiknas. 2007. Permendiknas Nomor 41 Tahun 2007 tentang Standar Proses Pendidikan Dasar dan Menengah. Jakarta.
Miftah, 2013. Pengembangan Perangkat Pembelajaran Berorientasi Metode Pembelajaran Penemuan Terbimbing Terhadap Pencapaian Keterampilan Proses Sains dan Keterampilan Berpikir Kritis Peserta Didik MAN 2 Model Makassar. Tesis. Program Pascasarjana UNM Makassar. Tidak diterbitkan.

Nurdin. 2007. Model Pembelajaran Matematika yang Menumbuhkan Kemampuan Metakognitif untuk Menguasai Bahan Ajar. Disertasi. Tidak diterbitkan. Surabaya: PPs UNESA

Patmawati,H. 2011. Analisis Keterampilan Berpikir Kritis Siswa pada Pembelajran Larutan Elektrolit dan Non Elektrolit dengan Metode Praktikum. Program Studi Pendidikan Kimia. UIN Syarif Hidayatullah Jakarta. Online (http://repository.uinjkt.ac.id/dspacel .../1 (diakses pada tanggal 30 Desember 2015)

Sanjaya. 2008. Strategi Pembelajaran Berorientasi Standar Proses pendidikan. Jakarta: Prenada Media Group.

Sohrah Saleh. 2015. Peningkatan Keterampilan Berpikir Kritis, Aktivitas, dan Hasil Belajar Kognitif Biologi Peserta Didik Kelas VIIA SMP Angkasa Maros melalui Penerapan Model Pembelajaran Inkuiri Terbimbing.Tesis. Program Pascasarjana UNM Makassar. Tidak diterbitkan

Sukardjo. 1990. Kimia Anorganik. Jakarta:Rineka Cipta.

Trianto. 2009. Mendesain Model Pembelajaran Inovatif Progresif. Jakarta: Kencana Prenata Media Group.

Trianto. 2013. Model Pembelajaran Terpadu. Jakarta: Bumi Aksara.

Uno, H.B.(2008). Perencanaan Pembelajaran . Jakarta: Bumi Aksara 
Chemistry Education Review, Pendidikan Kimia PPs UNM, 2018, Vol.1, No.2 (13-28)

Zaki,I. (2014). Berpikir Kritis. Online.

http://

zaki.blogspot.cpm.2014/12/berpikir

kritis.html...(diakses pada tanggal 16

Desember 2015)

Zubaidah, S.Mahanal,S. Yuliati,L. \& Sigit,

D. (2014). Buku Guru Ilmu Pengetahuan Alam SMP/MTs VIII.

Jakarta: Pusat Kurikulum dan

Perbukuan Balitbang. Kementrian

Pendidikan dan Kebudayaan. 